\title{
KAJIAN STOK IKAN PELAGIS KECIL DENGAN ALAT TANGKAP MINI PURSE SEINE DI PERAIRAN LEMPASING, LAMPUNG
}

\author{
Riena F. Telussa
}

1 Fakultas Perikanan dan IImu Kelautan, Universitas Satya Negara Indonesia

\begin{abstract}
Pelagic fish resources are the fish resources that lives in the sea or in the surface waters and generally consists of small fish such as mackerel (Rastrelliger spp.), Trevally fish (Selaroides spp.) Kite (Decapterus spp.) And many others. Small pelagic fish have high economic value and so many people who consume it. These conditions have encouraged fishermen to catch as many fish as possible even to the level of exploitation before preceded by fishing or other fishing companies. When used to over-exploitation level, these resources will be disrupted continuity and can eventually lead to extinction. Therefore any area used for fishing effort needs to know the number of potential existing in this waters in order to fish resources remain sustainable it is necessary to study the magnitude of the stock of fish. Fisheries stock assessment aims to optimally exploit aquatic resources, which means also an effort to raise the level of utilization in the long term provide maximum catches in the form of weights.

Data analysis of catch and fishing effort include the catch per unit effort (CPUE), the potential for sustainable (MSY) and $f$ OPT. Resource utilization rate can be calculated using the analysis method with the application of surplus production Schaefer method. CPUE values occurred in 2008 at 9.23 tons per unit but the highest catches in 2011 amounted to 2.355.31 tons, while the highest fishing effort occurred in 2011 amounted to 457 units. The smallest value of CPUE occurred in 2005 at 4.01 tons per unit, as well as catches the smallest occurred in 2005 amounted to 657.75 tons and the smallest fishing effort occurred in 2006 amounted to 145 units.

Application of the method surplus production, optimum effort values obtained with the first derivative of the equation of the relationship between CPUE and fishing effort. Optimum Effort Values obtained by 756.02 units per year. MSY values obtained during the period 2005-2011 amounted to 3.187.25 tons per year. While the rate of utilization of small pelagic fish in the waters of the highest Lempasing occurred in 2011 amounted to $73.90 \%$ and the lowest occurred in 2005 was $20.64 \%$, with an average value of $49.42 \%$ per year. Of the value of the average utilization rate of $49.42 \%$ and by MSY 3.187 .25 tons per year during the years 2005-2011 were obtained indicating that the use of small pelagic fish annually will increase but not exceed MSY, but if it is associated with a number of catches allowed (JTB) ie $80 \%$ of the MSY (2.549.80 tons per year) and is nearing MSY, with optimum effort of 756.02 units per year, shows that the insistence on small pelagic fish in the waters of the Sea Lempasing not exceed fopt.

By using the method of Schaefer obtained a relationship between fishing effort and catch per unit of fishing effort by the regression equation, the value of the intercept $(a)=$ 8.431, slope $(b)=-0.005$ and $R 2=0.099$
\end{abstract}

Keyword: catches, analysis of catch, method surplus production 


\begin{abstract}
Abstrak
Sumberdaya ikan pelagis merupakan sumberdaya ikan yang hidupnya di permukaan laut ataupun di permukaan perairan dan umumnya terdiri atas ikan yang berukuran kecil seperti ikan kembung (Rastrelliger spp.), selar (Selaroides spp.) layang (Decapterus spp.) dan masih banyak lagi lainnya. Ikan pelagis kecil mempunyai nilai ekonomis tinggi dan sangat banyak orang yang mengkonsumsinya. Kondisi tersebut telah mendorong nelayan untuk menangkap ikan sebanyak mungkin bahkan sampai tingkat eksploitasi berlebihan sebelum didahului oleh nelayan atau perusahaan perikanan yang lainnya. Apabila dimanfaatkan sampai tingkat eksploitasi berlebihan, sumberdaya tersebut akan terganggu kelestariannya dan akhirnya dapat mengakibatkan kepunahan. Oleh karena itu setiap wilayah yang dimanfaatkan untuk usaha penangkapan ikan perlu diketahui jumlah potensinya yang ada di perairan tersebut agar sumberdaya ikan tetap lestari maka perlu dilakukan pengkajian besarnya stok sumberdaya ikan tersebut. Pengkajian stok sumberdaya perikanan bertujuan untuk memanfaatkan sumberdaya perairan secara optimal, yang berarti pula sebagai upaya peningkatan tingkat pemanfaatan dalam jangka panjang yang memberikan hasil tangkapan yang maksimal dalam bentuk bobot.

Analisis data hasil tangkapan dan upaya penangkapan meliputi catch per unit effort (CPUE), potensi lestari (MSY) dan fopt. Tingkat pemanfaatan sumberdayanya dapat dihitung menggunakan analisis metode surplus produksi dengan penerapan metode Schaefer. Nilai CPUE terbesar terjadi pada tahun 2008 sebesar 9,23 ton per unit namun hasil tangkapan tertinggi terjadi pada tahun 2011 sebesar 2.355,31 ton, sedangkan upaya penangkapan tertinggi terjadi pada tahun 2011 sebesar 457 unit. Nilai CPUE terkecil terjadi pada tahun 2005 sebesar 4,01 ton per unit, demikian pula hasil tangkapan terkecil terjadi pada tahun 2005 sebesar 657,75 ton dan upaya penangkapan terkecil terjadi pada tahun 2006 sebesar 145 unit.

Penerapan metode surplus produksi, didapatkan nilai effort optimum dengan turunan pertama dari persamaan hubungan antara CPUE dan upaya penangkapan. Nilai Effort optimum didapatkan sebesar 756,02 unit per tahun. Nilai MSY yang didapatkan selama kurun waktu 2005-2011 sebesar 3.187,25 ton per tahun. Sedangkan Tingkat Pemanfaatan ikan pelagis kecil di perairan Lempasing tertinggi terjadi pada tahun 2011 sebesar $73,90 \%$ dan terendah terjadi pada tahun 2005 sebesar $20,64 \%$, dengan nilai rata-rata pertahunnya sebesar 49,42\%. Dari nilai tingkat pemanfaatan rata-rata 49,42\% dan nilai MSY 3187,25 ton per tahun yang didapatkan selama tahun 2005-2011 mengindikasikan bahwa pemanfaatan ikan pelagis kecil setiap tahunnya meningkat akan tetapi belum melebihi nilai MSY, namun apabila dikaitkan dengan jumlah tangkapan yang diperbolehkan (JTB) yaitu $80 \%$ dari nilai MSY (2.549,80 ton per tahun) dan hampir mendekati nilai MSY, dengan nilai effort optimum 756,02 unit per tahun, menunjukan bahwa pengupayaan ikan pelagis kecil di perairan Laut Lempasing belum melebihi fopt.

Dengan menggunakan metode Schaefer diperoleh hubungan antara upaya penangkapan dan hasil tangkapan per satuan upaya penangkapan dengan persamaan regresi, nilai intersep $(a)=8,431$, slop $(b)=-0,005$ dan $R^{2}=0,099$.
\end{abstract}

Kata Kunci: Hasil Tangkapan, Analisis Hasil Tangkapan, Metode Surplus Produksi 


\section{Pendahuluan}

Secara umum perikanan Indonesia bersifat terbuka (open access), dimana nelayan dapat dengan bebas melakukan usaha penangkapan ikan di laut. Kondisi yang demikian telah mendorong nelayan untuk menangkap ikan sebanyak mungkin sebelum didahului oleh nelayan atau perusahaan perikanan yang lainnya. Sumberdaya perikanan termasuk kedalam sumberdaya yang memiliki kemampuan untuk dapat memperbaharui dirinya (renewable), namun apabila dimanfaatkan sampai tingkat eksploitasi berlebihan, sumberdaya tersebut akan terganggu kelestariannya dan akhirnya dapat mengakibatkan kepunahan. Sektor perikanan memberikan konstribusi terhadap pembangunan nasional berupa penyediaan bahan pangan bergizi tinggi, memenuhi kebutuhan protein hewani masyarakat, lapangan perkerjaan, aktifitas perekonomian dan ikut berperan dalam menunjang keberhasilan pembangunan yang berkelanjutan. Pemanfaatan potensi sumberdaya harus dilakukan secara terkontrol, sehingga kelestarian sumberdaya ikan di setiap wilayah perairan senantiasa dapat dipertahankan agar produktifitas optimum dapat terjaga. Oleh karena itu setiap wilayah yang dimanfaatkan untuk usaha penangkapan ikan perlu diketahui jumlah potensinya yang ada di perairan tersebut agar sumberdaya ikan tetap lestari maka perlu dilakukan pengkajian besarnya stok sumberdaya ikan tersebut.

Pengkajian stok sumberdaya perikanan bertujuan untuk memanfaatkan sumberdaya perairan secara optimal, yang berarti pula sebagai upaya peningkatan tingkat pemanfaatan dalam jangka panjang yang memberikan hasil tangkapan yang maksimal dalam bentuk bobot. Pengkajian stok dilakukan dengan mengendalikan intensitas penangkapan hingga tercapainya pengusahaan yang secara ekonomi menguntungkan. Upaya pengkajian stok sudah lama dan banyak diterapkan dalam bentuk survei lapangan dan analisis data perikanan yang ada. Pengkajian dengan analisis data dilakukan dengan menggunakan model surplus produksi, dimana pengkajian diasumsikan dengan perhitungan stok tunggal dan upaya penangkapan tunggal.

Sumberdaya ikan pelagis merupakan sumberdaya ikan yang hidupnya di permukaan laut ataupun di permukaan perairan dan umumnya terdiri atas ikan yang berukuran kecil seperti ikan kembung (Rastrelliger spp.), selar (Selaroides spp.) layang (Decapterus spp.) dan masih banyak lagi lainnya. (Amin dalam Tiennansari, 2000). ikan-ikan pelagis kecil mempunyai karakteristik tertentu dalam penyebarannya. pada malam hari ikan-ikan pelagis kecil menyebar merata pada kolam perairan dan lebih dekat ke permukaan, sedangkan pada siang harinya ikan ini berada pada kedalaman tertentu yang merupakan batas aman dari lapisan renang (swimming layers) dari pergerakan ikan. Hal-hal yang menyebabkan ikan membentuk gerombolan antara lain adalah (1) sebagai perlindungan diri dari pemangsa atau predator, (2) mencari dan menangkap mangsa, (3) memijah, (4) musim dingin (5) ruaya dan pergerakan (6) pengaruh fakor lingkungan Gunarso (1985)

Salah satu kegiatan perikanan tangkap di Propinsi Lampung adalah perairan Lempasing, daerah ini terletak di wilayah Selatan Sumatera dari Bengkulu serta berhubungan langsung dengan Samudra Hindia. Hasil tangkapan sumberdaya ikan pelagis kecil yang didaratkan di Teluk Lampung sangat banyak dan beragam jenis Ikan yang banyak didaratkan di PPI Lempasing terdiri dari berbagai jenis ikan, diantaranya adalah kembung (Rastrelliger spp.), layang (Decapterus spp.), teri (Stolephorus spp.), selar (Selaroides spp.), dan lemuru (Sardinella longiceps). dan masih banyak jenis ikan lainnya. Ikan selar (Selaroides spp.) dan ikan layang (Decapterus spp.) merupakan ikan pelagis kecil dan termasuk salah satu jenis ikan yang mempunyai nilai ekonomis penting. Melihat kondisi tersebut maka penelitian mengenai kajian stok ikan pelagis kecil dengan alat tangkap mini purse seine di perairan Lempasing, Lampung perlu dilakukan. Penelitian ini dilakukan untuk mengetahui tingkat pemanfaatan ikan dan kecenderungan perkembangan hasil tangkapan ikan pelagis kecil di PPP Lempasing. 


\section{Metodelogi Penelitian}

Penelitian ini dilaksanakan bersama Kantor Balai Penelitian Perikanan Laut Muara Baru Jakarta utara pada bulan September-Desember 2013 yang bertempat di Pelabuhan Perikanan Pantai Lempasing (PPP) Kota Bandar Lampung-Sumatra selatan Data yang di kaji dalam penelitian berupa data primer yang diperoleh dengan cara monitoring, serta data sekunder yang diperoleh dengan cara wawancara. Seluruh data yang diperoleh ditabulasi dan diolah untuk mencapai tujuan penelitian. Analisis data hasil tangkapan dan upaya penangkapan meliputi catch per unit effort (CPUE) dan metode surplus produksi (potensi lestari (MSY) dan fopt).

Perhitungan CPUE bertujuan untuk mengetahui kelimpahan dan tingkat pemanfaatan ikan yang didasari atas pembagian total hasil tangkapan (catch) dengan upaya penangkapan (effort). Menurut Gulland (1983), rumus yang digunakan adalah sebagai berikut:

\section{CPUE}

Dimana:

Catch : Total hasil tangkapan (ton)

Effort : Total upaya penangkapan (trip)

CPUE : Hasil tangkapan per upaya penangkapan (ton/trip)

Pendugaan upaya penangkapan optimum $\left(f_{\text {opt }}\right)$ dan hasil tangkapan maksimum yang lestari (MSY) dapat dihitung dengan model Schaefer (Pauly, 1984). Gulland (1983), menyatakan bahwa hubungan antara hasil tangkapan per satuan upaya (CPUE) dan upaya (effort) dapat berupa hubungan linear maupun eksponensial.

Menurut Schaefer dalam Handoyo, (1991), hubungan effort dan catch menghasilkan kurva yang berbentuk parabola yang simetris. Formula yang disajikan adalah:

1. Hubungan antara CPUE dengan Upaya Penangkapan (f)

2. Hubungan antara hasil tangkapan (c) dan upaya penangkapan (f)

(c)

3. Effort optimum diperoleh dari turunan persamaan ke dua (2) sama dengan nol (0) yaitu:

(c)

4. Produksi maksimum lestari (MSY) diperoleh dengan mensubsitusikan nilai effort optimum ke dalam persamaan ke dua (2) yaitu: 
(c)

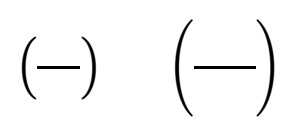

Dimana:

$\mathrm{a}=$ intercep

$\mathrm{b}=$ slop

$\mathrm{f}=$ upaya penangkapan (unit)

$\mathrm{c}=$ hasil tangkapan (catch)

Langkah-langkah untuk menghitung CPUE dengan menggunakan rumus metode Schaefer sebagai berikut:

a) Membuat tabel data catch (c) dan upaya penangkapan (f) serta menghitung CPUE

b) Memplotkan nilai CPUE terhadap nilai $f$ yang bersangkutan dan menghitung intersep (a) dan gradien (b) dengan menggunakan teknik linear.

c) Menghitung $\mathrm{f}_{\text {optimum }}$

d) Menghitung Maksimum Sustainable Yield (MSY)

Selanjutnya untuk menghitung tingkat pemanfaatan ikan digunakan persen jumlah hasil tangkapan pada tahun tertentu dengan nilai produksi maksimum lestari (MSY), yaitu:

Tingkat Pemanfaatan $=$

Dimana:

$\mathrm{Ci}=$ Jumlah tangkapan ikan pada tahun ke-i

MSY = Maksimum Sustainable Yield

Besarnya a dan b dapat dicari dengan menggunakan persamaan:

$$
\frac{\left(\sum X i\right)\left(\sum \quad i\right)}{\left(\sum \mathrm{i}\right)}
$$

Dimana:

$\mathrm{Xi}=$ Effort pada periode ke- $\mathrm{i}$

$\mathrm{Yi}=$ CPUE pada periode ke-i

$\mathrm{n}$ = Jumlah tahun

\section{Hasil dan Pembahasan}

Hasil survey dan observasi yang dilakukan selama penelitian mengenai kajian stok ikan pelagis kecil dengan alat tangkap mini purse seine di perairan Lempasing Lampung diperoleh data sebagai berikut: 


\section{Hasil Tangkapan}

Hasil tangkapan ikan pelagis kecil yang didaratkan di PPP Lempasing dalam kurun waktu 7 tahun yaitu, tahun 2005-2011 mengalami fluktuasi yang signifikan setiap tahunnya dapat dilihat pada Gambar 1.

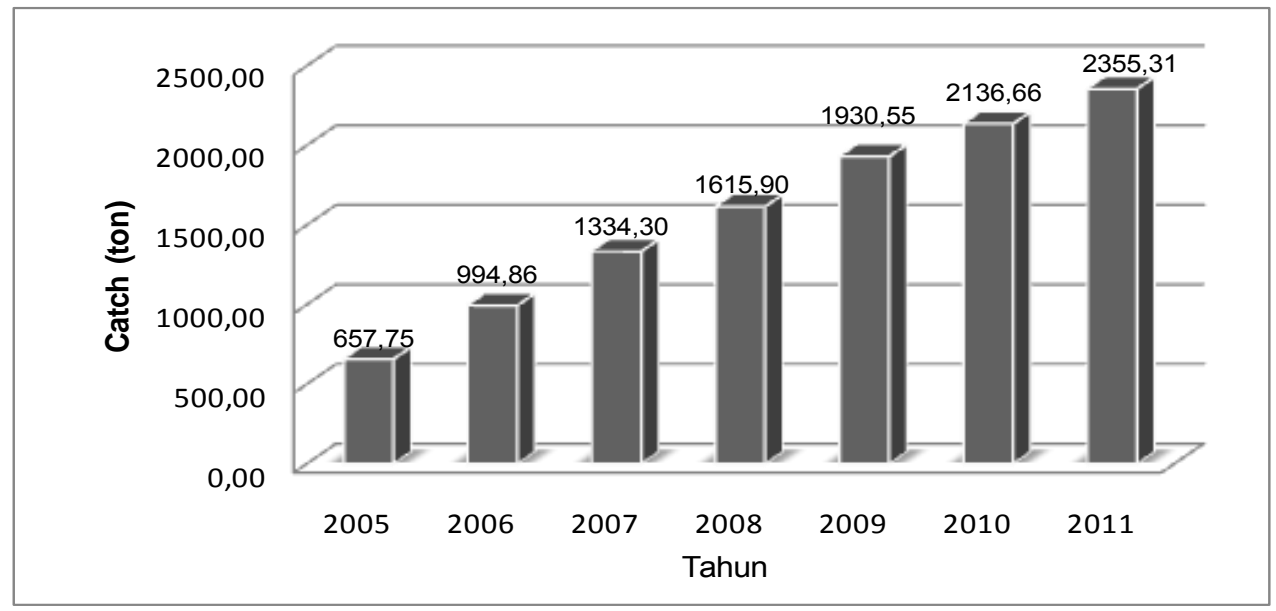

Gambar 1. Fluktuasi Hasil Tangkapan Ikan yang Didaratkan di PPP Lempasing Tahun 20052011

Hasil tangkapan pada tahun 2005 sebesar 657,75 ton tahun 2006 hasil tangkapan meningkat menjadi 998,86 ton, tahun 2007 meningkat lagi menjadi 1334,30 ton, tahun 2008 terus meningkat menjadi 1615,90 ton, tahun 2009 meningkat lagi menjadi 1930,55, tahun 2010 meningkat terus menjadi 2136,66 ton dan tahun 2011 meningkat kembali menjadi 2355,31 ton. Hasil tangkapan pada tahun 2005 merupakan hasil tangkapan terendah dalam kurun waktu tujuh tahun terakhir sedangkan hasil tangkapan pada tahun 2011 merupakan hasil tangkapan tertinggi. Hasil tangkapan tinggi yang terjadi selama tiga tahun terakhir yaitu pada tahun 2009-2011 diduga ikan pelagis kecil yang ada di perairan Lempasing pada saat itu berlimpah.

\section{Upaya Penangkapan}

Upaya (unit) penangkapan ikan pelagis kecil dalam kurun waktu 7 tahun yaitu, dari tahun 2005-2011 mengalami fluktuasi yang signifikan. setiap tahunnya dapat dilihat pada Gambar 2.

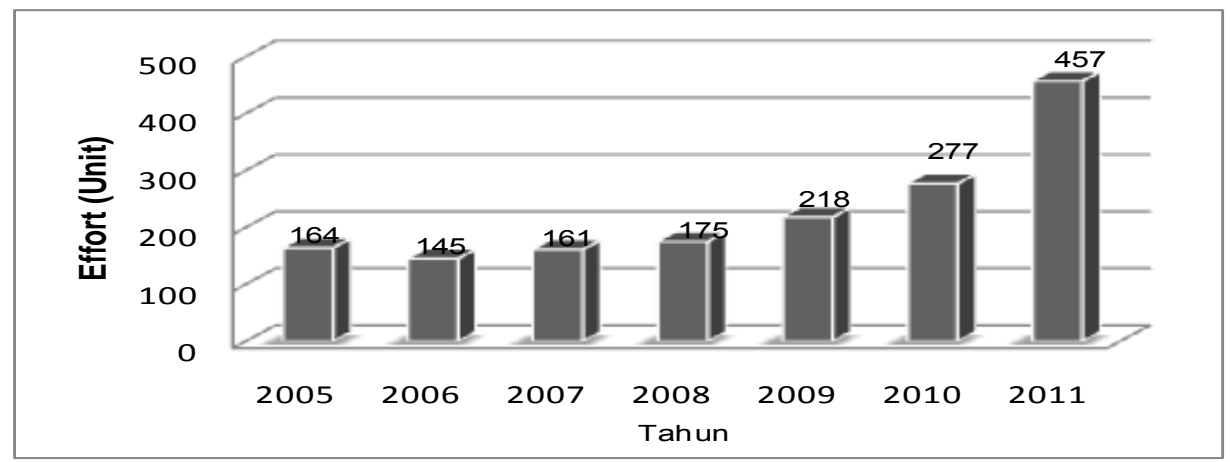

Gambar 5. Fluktuasi Upaya Penangkapan Ikan yang Didaratkan di PPP Lempasing Tahun 2005-2011 
Upaya penangkapan pada tahun 2005 sebanyak 164 unit, tahun 2006 upaya penangkapan mengalami penurunan menjadi 145 unit, tahun berikutnya 2007 unit penangkapan mengalami peningkatan menjadi 161 unit dan pada tahun 2008 upaya penangkapan meningkat menjadi 175 unit dan pada tahun 2009 upaya penangkapan meningkat menjadi 218 unit dan pada tahun 2010 upaya penangkapan meningkat lagi menjadi 277 unit. Upaya penangkapan tertinggi terjadi pada tahun 2011 yaitu sebesar 457 unit dan upaya penangkapan terendah terjadi pada tahun 2006 sebesar 145 unit. Peningkatan upaya penangkapan pada tahun 2010 dan 2011 disebabkan karena harga ikan di pasar pada saat itu tinggi dan juga karena cuaca yang mendukung, jadi para nelayan setempat banyak yang melakukan operasi penangkapan. Selain itu, juga didukung dengan keadaan perairan yang subur yang diakibatkan oleh proses upwelling sehingga di perairan tersebut banyak makanan bagi ikan. Sudah menjadi ketentuan bahwa sifat ikan beruaya dan migrasi ke perairan yang kaya akan makanannya

\section{Hasil Tangkapan Per Satuan Upaya Penangkapan}

Hasil tangkapan per satuan upaya penangkapan atau Catch Per Unit Effort (CPUE) sangat penting dalam pengawasan dan pengendalian penangkapan. Dalam sumberdaya perikanan penghitungan CPUE bertujuan untuk mengetahui tingkat pemanfaatan ikan dan kecenderung perkembangan hasil tangkapan ikan yang didaratkan di PPP Lempasing. Nilai hasil tangkapan per satuan upaya penangkapan ikan pelagis kecil yang didaratkan di PPP Lempasing tahun 2005-2011 disajikan pada Gambar 3.

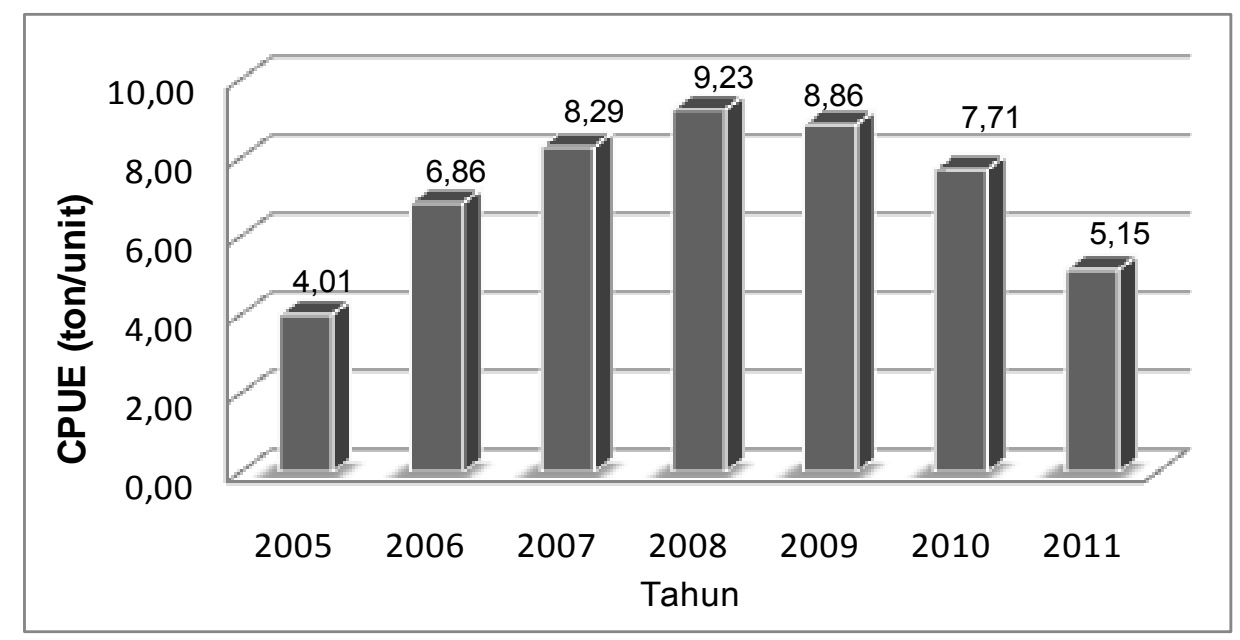

Gambar 3. Fluktuasi Catch Per Unit Effort (CPUE) di PPP Lempasing Tahun 2005-2011

Gambar 3 menunjukan bahwa nilai CPUE selama tahun 2005-2011 mengalami fluktuasi yang cukup signifikan. Nilai CPUE yang terjadi pada tahun 2005 sebesar 4,01 ton/unit, pada tahun 2006 meningkat menjadi 6,86 ton/unit, pada tahun 2007 meningkat lagi menjadi 8,29 ton/unit, dan pada tahun 2008 meningkat terus menjadi 9,23 ton/unit, untuk tahun selanjutnya mengalami penurunan menjadi 8,86 ton/unit pada tahun 2009 , pada tahun 2010 menurun kembali menjadi 7,71 ton/unit dan pada tahun 2011 mengalami penuruna lagi menjadi 5,51 ton/unit. Untuk nilai CPUE tertinggi terdapat pada tahun 2008 sebesar 9,23. Hal ini berarti , penaikan upaya penangkapan tidak akan selalu menaikan nilai CPUE, bahkan sebaliknya. Sesuai dengan pernyatan Genisa (1998) bahwa tingkat pengupayaan yang tinggi menurunkan nilai CPUE artinya, tingkat pengupayaan berbanding terbalik dengan nilai CPUE, dan juga sesuai dengan pernyataan Ali (2005) bahwa penambahan upaya penangkapan tidak dapat lagi meningkatkan nilai CPUE atau penambahan upaya selalu diikuti dengan penurunan nilai CPUE. 
Penurunan nilai CPUE yang disebabkan karena penaikan upaya penangkapan, juga berpengaruh terhadap hubungan antara Cacth, dengan mengaikan antara Effort dan Cacth kita bisa mengetahui trend fluktuasinya. Hubungan antara CPUE dengan Effort disajikan pada Gambar 4. Terlihat bahwa upaya penangkapan meningkat secara signifikan yang terjadi pada tahun 2011 dan diikuti dengan penurunan nilai CPUE. Dengan persamaan regresi yang diperoleh adalah nilai Intersep $(a)=8,431$, slop $(b)=-0,005$ dan nilai $R^{2}$ $=0,099$

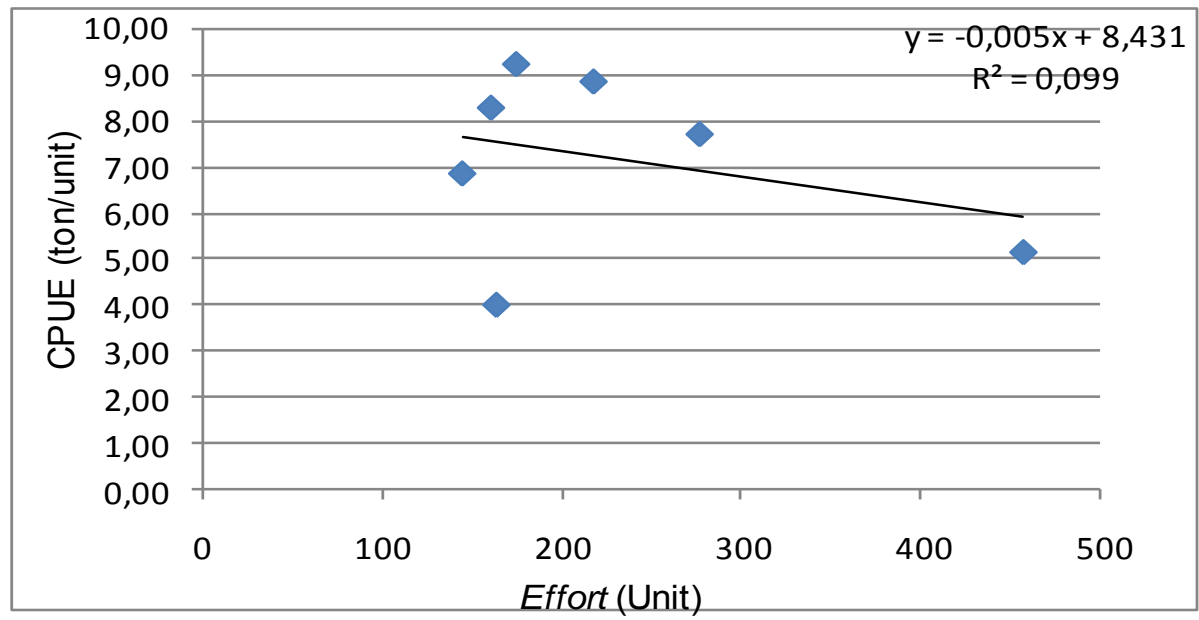

Gambar 4.. Grafik Hubungan antara CPUE dan Effort.

4. Metode Surplus Produksi

Model surplus produksi digunakan untuk mengetahui atau mengkaji potensi lestari dan tingkat pemanfaatan sumber daya perikanan dalam suatu perairan. Yang mana dalam Model Produksi Surplus ini digunakan metode Schafer untuk mencari potensi lestari (MSY), fopt dan tingkat pemanfaatan.

\section{Maximum Sustainable Yield (MSY)}

Hasil tangkapan maksimum lestari adalah besarnnya jumlah ikan yang dapat ditangkap secara terus menerus dari suatu sumberdaya tanpa mempengaruhi kelestarian stok ikan. Hal ini dapat juga digunakan untuk menduga fluktuasi kelimpahan suatu jenis ikan dan menggambarkan biomassa ikan-ikan di suatu perairan.

Nilai potensi lestari yang diperoleh dari perhitungan nilai CPUE selama periode 20052011 adalah sebesar 3187,25 ton per tahun. Grafik hubungan antara Catch dan effort tersebut seperti terlihat pada Gambar 4. yang juga menunjukan nilai effort optimum sebesar 756,02 unit per tahun. Dengan menggambarkan model surplus produksi untuk hubungan antara upaya penangkapan (effort) dengan hasil tangkapan per satuan upaya penangkapan (CPUE) diperoleh potensi lestari maksimum (MSY) ikan sebesar 3187,25 ton per tahun. Potens lestari maksimum merupakan suatu nilai batas dimana sumberdaya ikan yang dapat dimanfaatkan tanpa mengganggu kelestarian untuk tumbuh dan menjaga keturunannya. Upaya penangkapan optimum (fopt) adalah besarnya upaya penangkapan yang dilakukan oleh unit penangkapan, agar mendapatkan hasil yang maksimal, tanpa merusak kelestarian sumberdaya yang ada. 


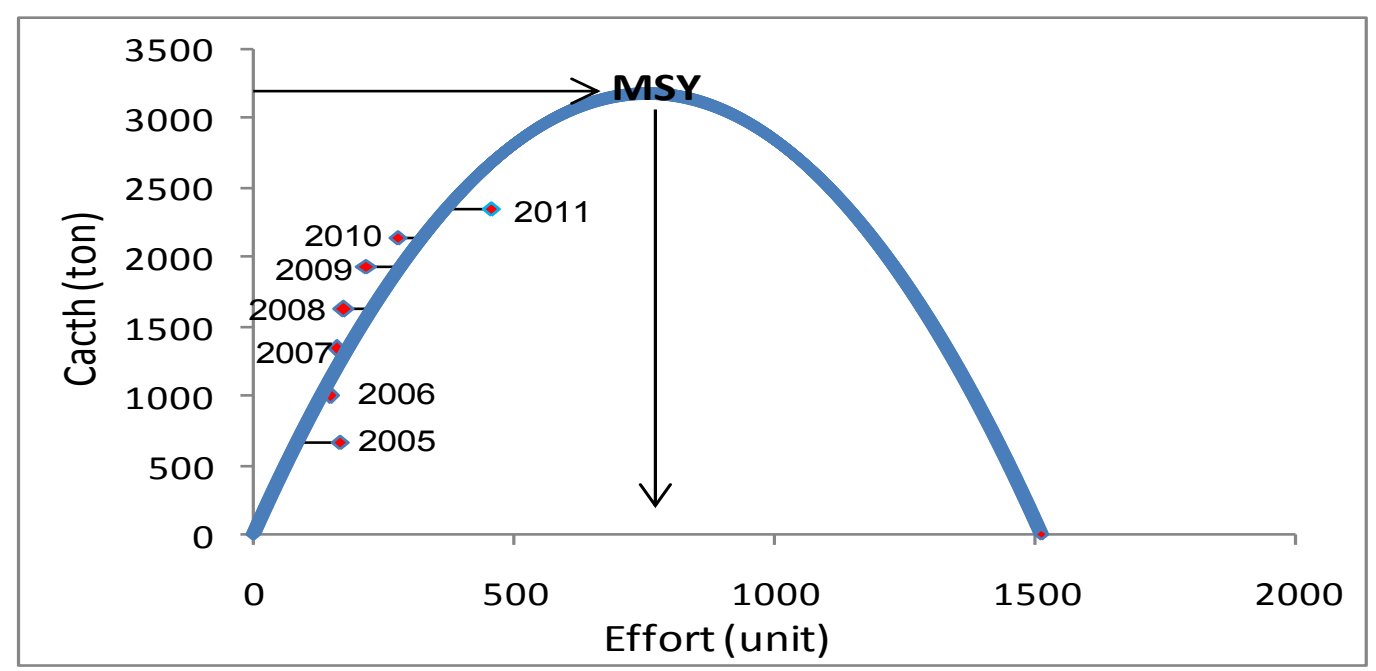

Gambar 5. Grafik Hubungan Catch dan Effort Ikan Selama Tahun 2005-2011 di PPP Lempasing.

Gambar 5 diketahui bahwa hubungan antara upaya penangkapan (effort) dengan produksi ikan (catch). Artinya dengan menambahkan effort 756,02 unit per tahun maka akan meningkatkan produksi maksimal sampai 3187,25 ton per tahun. Sehingga untuk pemanfaatan sumberdaya ikan secara berkelanjutan maka upaya penangkapan tidak boleh melebihi 756,02 unit per tahun dengan produksi maksimal lestari (MSY) 3187,25 ton per tahun. Kurva hubungan antara cath dan effort menunjukan bahwa pada tahun 2005, dan 2006 produksi hasil tangkapan belum melebihi MSY dengan upaya dibawah fopt, pada tahun 2007-2010 produksi hasil tangkapan meningkat dan berada di luar kurva MSY yang artinya produksi pada tahun 2007-2010 tidak sustainable, akan tetapi belum melebihi MSY dan pada tahun 2011 produksi hasil tangkapan meningkat dengan diikuti meningkatnya upaya penangkapan akan tetapi belum melebihi MSY dan fopt. Dari uraian Gambar 5 dapat kita ketahui bahwa produksi hasil tangkapan ikan selama 7 tahun terakhir 2005-2011 belum melebihi MSY dan upaya penangkapannya juga belum melebihi fopt jadi dapat dikatakan jumlah ikan yang ada di perairan Lempasing masih banyak dan berlimpah. Akan tetapi untuk menjaga keletariannya perlu adanya pengawasan dan pengontrolan yang bijaksana agar kelestariannya dapat terjaga terus.

\section{Tingkat Pemanfaatan}

Adanya nilai MSY untuk sumberdaya ikan dapat dimanfaatkan untuk mengetahui tingkat pemanfaatan sumberdaya tersebut. Tingkat pemanfaatan menunjukan kemampuan dalam memanfaatkan sumberdaya perikanan yang ada. Tingkat pemanfaatan merupakan kemampuan nelayan Lempasing untuk memanfaatkan sumberdaya ikan yang tersedia di perairan Lempasing. Tabel 1 menunjukan tingkat pemanfaatan yang tinggi pada tahun 2011 sebesar 73,90 \% dan tingkat pemanfaatan terendah terjadi pada tahun 2005 sebesar 20,26 \%. Tingkat pemanfaatan ikan pada tahun 2006-2011 cukup berfluktuasi, yang pada umumnya meningkat terus. 
Tabel 1. Tingkat Pemanfaatan Ikan di Perairan Lempasing Selama Tahun 2006-2011.

\begin{tabular}{|l|l|l|}
\hline Tahun & Catch (ton) & Tingkat Pemanfaatan (\%) \\
\hline 2005 & 657,75 & 20,64 \\
\hline 2006 & 994,86 & 31,21 \\
\hline 2007 & 1334,30 & 41,86 \\
\hline 2008 & 1615,90 & 50,70 \\
\hline 2009 & 1930,55 & 60,57 \\
\hline 2010 & 2136,66 & 67,04 \\
\hline 2011 & 2355,31 & 73,90 \\
\hline Rata-rata & 49,42 \\
\hline
\end{tabular}

Berdasarkan rata-rata tingkat pemanfaatan sebesar $49,42 \%$ per tahunnya dapat dikatakan bahwa tingkat pemanfaatan sumberdaya ikan di perairan Lempasing oleh nelayan setempat setiap tahunnya meningkat akan tetapi belum melebihi nilai MSY, namun apabila dikaitkan dengan jumlah tangkapan yang diperbolehkan (JTB) yaitu $80 \%$ dari nilai MSY (2549,80 ton per tahun) dan hampir mendekati nilai MSY. Oleh karena itu perlu ke hati-hatian dalam pemanfaatannya karena tanpa ada pengontrolan dan pengawasan akan mengakibatkan over fishing dan produksi yang berlebihan yang akibatnya populasi ikan yang ada di perairan Lempasing terancam kelestariannya.

Upaya pengelolaan sumberdaya ikan dapat dilakukan melalui pengaturan upaya penangkapan baik berupa jumlah trip maupun jumlah alat tangkap yang digunakan dalam mengeksploitasi serta pengaturan kuota penangkapan, untuk menghindari over exploitasi yang dapat menyebabkan overfishing secara biologi (biological overfishing) karena dapat melewati nilai maksimum lestari (MSY). Dimana menurut Widodo dan Suadi (2006), bahwa biological overfishing akan terjadi manakala tingkat upaya penangkapan dalam suatu perikanan tertentu telah melampaui tingkat yang diperlukan untuk menghasilkan potensi maksimum lestari (MSY), namun dapat dicegah dengan melakukan pengaturan upaya penangkapan dan pola penangkapan. 


\section{Kesimpulan}

1. Nilai hasil tangkapan per satuan upaya penangkapan di perairan Lempasing selama tahun 2005-2011 mengalami fluktuasi yang signifikan. Pada tahun 2005-2008 fluktuasi meningkat terus dan pada tahun 2009-2011 nilai hasil tangkapan per satuan penangkapan menurun. Nilai hasil tangkapan per satuan upaya penangkapan yang tertinggi terjadi pada tahun 2008 sebesar 9,23 ton/unit Hal ini berarti , penaikan upaya penangkapan tidak akan selalu menaikan nilai CPUE bahkan sebaliknya, dan nilai hasil tangkapan per satuan penangkapan yang terendah terjadi pada tahun 2005 sebesar 4,01 ton/unit. Selain faktor upaya, diduga peningkatan nilai CPUE pada tahun 2008 terkait dengan melimpahnya ikan di perairan Lempasing, sementara itu keadaan laut yang relatif tenang dan cuaca yang mendukung, sehingga proses penangkapan berjalan dengan lancar.

2. Terkait dengan potensi pemanfaatan ikan di perairan Lempasing, diperoleh nilai MSY 3187,25 ton per tahun dan upaya fopt 756,02 unit per tahun dan belum melebihi hasil produksi yang diperoleh dan upaya. Serta nilai MSY juga belum melebihi jumlah tangkapan yang diperbolehkan (JTB) yaitu $80 \%$ dari nilai MSY (2549,80 ton per tahun)

\section{DAFTAR PUSTAKA}

Ali, TH. 2005. Prinsip-prinsip Network Planning. Jakarta : PT Gramedia. 309 hal.

Amin, E.M. 1979. Suatu Analisa tentang Potensi Perairan di Selat Sunda. Lembaga Penelitian Perikanan Laut. No. PL 001/79. Jakarta. 19 hlm.

Genisa, A. S. 1998. Beberapa Catatan Tentang Alat Tangkap Ikan Pelagis Kecil. Balitbang Biologi Laut. Puslitbang Oseanologi-LIPI. Jakarta.

Gulland, JA. 1983. Fish Stock Assessment: a Manual of Basic Methods, volume 1.John Wiley \& Sons, inc. New York, USA. xii + 223 p.

Gunarso, W. 1985. Tingkah Laku Ikan. Bahan Pengajaran (tidak dipublikasikan). Fakultas Perikanan, Institut Pertanian Bogor, Bogor. 148 halaman.Tiennansari, A. 2000. Studi Tentang Sumberdaya Ikan Pelagis Kecil Utama yang Didaratkan di Propinsi Bengkulu. (Skripsi, tidak dipublikasikan). Program Studi Pemanfaatan Sumberdaya Perikanan, Fakultas Perikanan dan Ilmu Kelautan, Institut Pertanian Bogor, Bogor 84 hal.

Pauly, D. 1984. Fish Population Dynamics in Tropical Waters : a Manual for Use With Programmable Calculators. ICLARM. Manila. Filipina.325 p.

Handoyo, D. 1991. Analisis Tingkat Pengusahaan Sumberdaya Ikan Kembung (Rastrelliger spp) pada Tiap Musim Penangkapan Ikan di Perairan Utara Jawa. Skripsi. Program Studi Ilmu dan Teknologi Kelautan, Fakultas Perikanan. IPB. Bogor. 115 hal.

Widodo, J dan Suadi. 2006. Pengelolaan Sumberdaya Perikanan Laut. Gajah Mada University Press. Yogyakarta.252 hlm. 